Enlighten: Jurnal Bimbingan Konseling Islam

Volume 1 No 1 (Januari-Juni 2018) Hlm: 88 - 94

Tersedia online di http://journal.iainlangsa.ac.id/index.php/enlighten

ISSN 2622-8912

\title{
PERANAN MODEL TEAM GAMES TOURNAMENT UNTUK MENINGKATKAN KEMAMPUAN BERBICARA DAN SELF CONFIDENCE
}

\author{
Syarifah Ainy Rambe, Marina Sari Rambe, Abdul Marif \\ Universitas Muslim Nusantara Al-Washliyah Medan \\ Universitas Muslim Nusantara Al-Washliyah Medan \\ Universitas Muslim Nusantara Al-Washliyah Medan \\ E-mail: ainainyipah@gmail.com
}

\begin{abstract}
Abstrak
Kemampuan berbicara sangatlah penting di dalam perkuliahan, namun pada kenyataannya mahasiswa masih merasa kesulitan dalam berkomunikasi, terutama ketika mengikuti mata kuliah bahasa inggris di jurusan bimbingan dan konseling dikarenakan kurangnya rasa percaya diri (self confidance). Hal tersebut tentunya dapat mengakibatkan hasil belajar mahasiswa yang tidak maksimal. TGT Model (Team Games Tournament) merupakan salah satu cara yang akan memperluas fikiran mahasiswa sehingga mahasiswa dapat lebih berfikir positif dan memiliki keberanian untuk mengungkapkan pendapatnya di depan umum, hal yang demikian itu tentunya dapat meningkatkan kemampuan berbicara mahasiswa. Metode yang digunakan adalah Classroom Action Research (CAR) dalam hal ini dilakukan dua putaran (cycling), setiap putaran (cycling) akan dilakukan perencanaan, tindakan, Observasi dan Refleksi. Data yang akan dihasilkan adalah data kuantitatif dan data kualitatif. Diperoleh data kemampuan berbicara mengalami peningkatan sebesar 29,5. Dari hasil siklus 1 sebesar 59,33 dan dari siklus 2 sebesar 88,83. Selain itu dari hasil observasi self confidance juga mengalami peningkatan sebesar $30 \%$ pada point $1.10 \%$ pada point $2.23 \%$ dari point 3 , dan $16 \%$ dari point 4 . Selain itu dari diary note juga menunjukkan adanya peningkatan keaktifan mahasiswa di dalam kelas. Dengan demikian, model TGT efektif dilakukan untuk meningkatkan kemampuan berbicara dan self confidence dalam mata kuliah Bahasa Inggris pada mahasiswa.
\end{abstract}

Kata Kunci: TGT Model, Kemampuan Berbicara, Self Confidence

\begin{abstract}
The ability to speak is very important in lectures, but in reality students still find it difficult to communicate, especially when attending English courses majoring in guidance and counseling due to self confidance. This certainly can lead to student learning outcomes that are not optimal. TGT Model (Team Games Tournament) is one way that will broaden
\end{abstract}


students 'minds so that students can think more positively and have the courage to express their opinions in public, such things can certainly improve students' speaking skills. The method used is Classroom Action Research (CAR) in this case carried out two rounds (cycling), each cycle (cycling) will be carried out planning, action, Observation and Reflection. The data to be produced are quantitative data and qualitative data. Obtained data on speaking ability increased by 29.5. From the results of the first cycle of 59.33 and from the second cycle of 88.83. In addition, the results of self-confidance observations also increased by $30 \%$ at point $1.10 \%$ at point $2.23 \%$ of point 3 , and $16 \%$ from point 4 . In addition, from the diary note also showed an increase in student activity in the classroom . Thus, the TGT model is effective to improve speaking skills and self confidence in English language courses for students.

Keywords: TGT Model, ability to speak, Self Confidence

\section{PENDAHULUAN}

Pada kurikulum saat ini Perguruan Tinggi mengharuskan kepada mahasiswanya untuk menguasi bidang ilmu yang mereka pilih, dengan kata lain mahasiswa dituntut untuk mampu mengkreasikan atau mengembangkan ilmu yang mereka dapatkan pada bidang ilmu yang mereka pilih. Pengembangan ilmu yang mereka kuasai nantinya akan mampu menghasilkan atau bahkan menerapkannya dalam dunia pekerjaan nantinya. Hal yang demikian ini membuat mahasiswa untuk menguasai bahasa terutama bahasa inggris. Penguasan mahasiswa pada mata kuliah bahasa inggris di jurusan bimbingan dan konseling sangatlah rendah, hal ini dapat dilihat dari observasi yang telah dilakukan peneliti terhadap mahasiswa jurusan bimbingan dan konseling. Penguasaan mahasiswa terhadap empat skills (reading, listening, writing, speaking) bisa dikatakan sangat tidak memuaskan, banyak mahasiswa yang menjalani mata kuliah bahasa inggris di jurusan bimbingan dan konseling tidak mampu menguasai bidang ilmu tersebut sehingga mahasiswa merasa kesulitan dan takut ketika proses belajar mengajar sedang berlangsung, khususnya pada matakuliah bahasa inggris, mata kuliah bahasa inggris merupakan satu mata kuliah yang menuntut mahasiswanya untuk mampu secara mandiri berbicara (speaking) dihadapan orang banyak. Hal ini disebabkan oleh kurangnya kepercayaan diri (self confidence) mahasiswa untuk berbicara di muka umum karena tidak memiliki banyak kosakata (vocabulary) dan tidak mampu menggunakan grammar dengan benar sehingga kalimat yang dihasilkan akan memiliki makna yang rancu.

Model TGT (Team Games Tournament) dirasa mampu untuk membantu menyelesaikan masalah tersebut. TGT (Team Games Tournament) merupakan model yang mampu mengasah kepercaya dirian mahasiswa, dengan menggunakan TGT mahasiswa akan 
diajarkan cara berkerja sama sehingga mereka dapat menyelesaikan sebuah masalah dalam tournament dan menyimpulkannya. Pada model ini peneliti akan membagi mahasiswa dalam beberapa group dengan kriteria yang berbeda, dengan kriteria yang berbeda diharapkan mahasiswa yang memiliki kemampuan kurang akan merasa tertantang untuk meningkatkan kepercayaan dirinya (self Confidence) dan kemampuan berbicaranya (Speaking skill) pada mata kuliah speaking. Selain daripada itu, melalui model ini juga diharapkan mahasiswa akan saling berbagi ilmu untuk mencapai nilai terbaik. Pada saat turnamen berlangsung juga mempengaruhi mahasiswa dalam berkerja sama dengan baik tanpa memilah teman yang memiliki kemampuan yang sama dengan mereka. Dengan demikian, peneliti akan mengangkat judul "Penerapan TGT (Team Games Tournament) Model dalam Peningkatan Kemampuan Berbicara dan Self Confidence pada Mahasiswa".

\section{METODE PENELITIAN}

Metode penelitian yang digunakan dalam penelitian ini adalah Classroom Action Research (CAR) yaitu penelitian yang berlandaskan untuk mengembangkan strategi pembelajaran yang paling efisien dan efektif secara alamiah berdasarkan tindakan (bukan Eksperimen). Desain yang digunakan pada penelitian ini adalah disain penelitian menurut Kemmis dan Taggart, dimana penelitian ini akan dilakukan sebanyak dua siklus (cycle) tiap satu putaran akan memiliki empat tahap.Tahap- tahap tersebut adalah Perencanaan Tindakan dan Observasi - Refleksi. Tindakan dan Observasi akan dilakukan secara bersamaan dalam satu waktu hal ini dikarenakan peneliti akan melakukan tindakan sekaligus melakukan observasi untuk mengamati perubahan mahasiswa setelah mendapatkan tindakan, setelah tindakan dan observasi selesai maka akan dilakukan refleksi untuk merencanakan tindakan yang akna dilakukan selanjutnya. Siklus (cycle) dalam Classroom Action Research (CAR) dilakukan sesuai dengan kehendak peneliti sampai peneliti memproleh hasil yang memuaskan, dalam penelitian ini peneliti hanya mengambil sebanyak tiga siklus (cyle) untuk memperoleh hasil yang maksimal. 


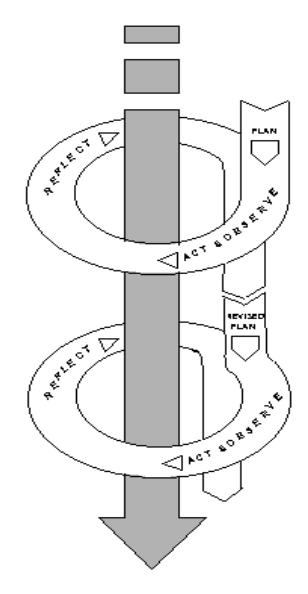

Gambar 1.

\section{Desain Penelitian oleh Kammis \& Taggart}

\section{HASIL PENELITIAN}

Penelitian ini dilakukan pada satu kelas dengan 30 orang mahasiswa. Penelitian ini dilakukan dua siklus yang setiap siklusnya terdapat empat tahap yakni perencanaan, tindakan dan observasi serta refleksi. Pada setiap siklus dilakukan empat kali pertemuan. Hasil kegiatan yang peneliti lakukan pada mahasiswa BK mengenai penerapan TGT model untuk meningkatkan kemampuan berbicara dan self confidence pada mahasiswa mengalami peningkatan dari mulai siklus 1 sampai siklus 2. Hal ini dapat dilihat dari hasil speaking test yang mengalami peningkatan sebesar 29,5. Pada siklus 1 speaking test mahasiswa berada pada angka 59,33 dan pada siklus 2 sebesar 88,83. Selain itu juga dapat dilihat dari peningkatan hasil observasi pada self confidance pada siklus 1 dan 2.

Tabel 1. Hasil Self Confidence Pada Siklus 1 dan Siklus 2

\begin{tabular}{|l|l|l|l|}
\hline No & Aspek Yang di Observasi & Siklus 1 & Siklus 2 \\
\hline 1 & $\begin{array}{l}\text { Mahasiswa dapat menjelaskan } \\
\text { kembali hasil diskusi }\end{array}$ & $50 \%$ & $80 \%$ \\
\hline 2 & $\begin{array}{l}\text { Mahasiswa mampu bertanya } \\
\text { Mahasiswa dapat maju didepan } \\
\text { kelas ketika menyampaikan } \\
\text { pendapatnya 43,3\% }\end{array}$ & $60 \%$ \\
\hline 4 & $\begin{array}{l}\text { Mahasiswa mampu } \\
\text { mengemukakan pendapatnya } \\
\text { tanpa ada keterpaksaan }\end{array}$ & $50 \%$ & $66,6 \%$ \\
\hline
\end{tabular}


Dari tabel di atas menunjukkan adanya peningkatan antara siklus 1 dan siklus 2, pada point 1 terdapat peningkatan sebesar 30\% artinya mahasiswa mulai dapat menjelaskan hasil diskusi, pada point 2 terdapat peningkatan sebesar 10\% artinya mahasiswa sudah mampu untuk bertanya didepan umum, pada point 3 terdapat peningkatan sebesar $23 \%$ artinya mahasiswa sudah mampu untuk mengemukakan pendapatnya di depan kelas, dan pada point 4 menunjukkan adanya peningkatan sebesar $16 \%$ artinya mahasiswa sudah mampu untuk mengemukakan pendapatnya tanpa adanya keterpaksaan.

\section{PEMBAHASAN}

Penerapan model TGT yang di aplikasi kan kepada mahasiswa menunjukkan adanya perubahan yang signifikan. Penelitian ini dilakukan dengan 2 siklus, dimana setiap siklus ada 4 tahapan yang dilakukan. Pada siklus pertama hasil yang di dapatkan mahasiswa masih belum menunjukkan adanaya perubahan yang signifikan kemampuan berbicara dan peningkatan self confidance nya. Selanjutnya penelitian ini dilakukan lagi dengan siklus yang kedua, dimana pada siklus ini juga di berikan 4 tahapan, dan hasil pada siklus ini mahasiswa sudah menunjukkan hasil yang siginifikan.

Mahasiswa sudah mampu untuk mengemukakan pendapatnya tanpa ada keterpaksaan dan tidak malu lagi ketika menyampaikan pendapat dengan menggunkana bahasa inggris di depan umum. Dengan demikian model TGT dapat digunakan untuk meningkatkan kemampuan berbicara dan self confidance mahasiswa pada mata kuliah bahasa inggris.

\section{KESIMPULAN}

Berdasarkan hasil penelitian dan pembahasan maka dapat disimpulkan sbb:

1. Penerapan TGT (Team Games Tournament) dapat menaikkan minat belajar mahasiswa terhadap bahasa asing, terutama dalam berbicara disepan kelas dengan menggunakan bahasa yang dianggap jarang digunakan dalam kehidupan sehari-hari.

2. Penerapan TGT (Team Games Tournament) dapat meningkatkan jumlah kosa kata mahasiswa terhadap bahasa asing sehingga mereka dengan mudah terpacu untuk menambah kosa kata setiap harinya.

3. TGT (Team Games Tournament) adalah merupakan games menarik yang bisa membantu dosen / guru dalam mengajarkan hal baru sehingga hal baru tersebut dapat dengan mudah dicerna oleh mahasiswa. 


\section{SARAN}

1. TGT (Team Games Tournament) dapat dipergunakan dalam proses belajar mengajar, terutaama pada topik pembelajaran yang dianggap cukup sulit bagi mahasiswa sehingga mahasiswa dapat berkolaborasi dan saling membantu untuk meningkatkan pemahaman terhadap topik pembelajaran tersebut.

2. Penerapan TGT (Team Games Tournament) tidak hanya dapat diberikan pada mahasiswa melainkan juga peserta didik tingkat Sekolah Menengah untuk lebih memudahkan proses belajar mengajar di dalam kelas.

3. Penerapan TGT (Team Games Tournament) cukup baik untuk diterapkan dalam proses belajar mengajar, hal ini juga ditinjau dari peningkatan kemampuan siswa yang saling menutupi satu sama lain sehingga tidak terjadi bullying dalam sistem pembelajaran yang akan membuat tingkat kepercayaan peserta didik semakin bertambah rendah dan menurunkan minat belajar peserta didik

\section{DAFTAR RUJUKAN}

Bashier et all., Factor Effecting Students' English Speaking Skill. British Journal of arts and Social Science. Vol 2 No 1. 2011. Hlm: 34 - 50.

De Angelis, B. 1997. Percaya diri sumber sukses dan kemandirian. Cetakan Pertama. Jakarta: Gramedia Pustaka Utama.

Depdikbud. 1992. Undang-Undang No. 20/2003. Depdikbud.

Di Matteo, M.R. \& Martin, L.R. 2002. Health psychology. Boston : Allyn \& Bacon.

Lee, A. 2004. 101 Cara Menumbuhkan Percaya Diri Anak (Usia Balita Sampai Remaja). Jakarta: PT. Elex Media Komputindo.

Liendenfiel, G. 1997. Mendidik anak agar percaya diri. Alih bahasa: Kamil, E Jakarta: Arcan.

Malendez, May et all., Teaching Speaking Strategies to Beginners. Eruropean Scientific Journal. Februari 2014 Volume . Hal: 548-554.

Murtono., Pengembangan Instrumen evaluasi dengan Tehnik Simulasi sebagai Assesmen Alternatif dalam Pembelajaran Fisika Materi Mekanika Fluida SMA Kelas XI. Jurnal Inovasi dan Pembelajaran Fisika. Volume 1 Nomor1 Mei 2014. Hal: 1-13. 
Pathan et all., Speaking in Their Language: an overview of Major difficulties Faced By the Libyan EFL Learners in Speaking skill. International Journal of English Language and Translation Studies. 2014. Hal: 96-105.

Putri, et all., Efektifitas Penggunaan Media Poster untuk Mengenalkan Pakaian Daerah bagi Anak Tunagrahita Ringan di SLB Alhidayah Padang. Jurnal Pendidikan Khusus. Nomor 3 September 2013. Hal: 141-152.

Supardi,. Peran Berfikir Kreatif dalam Proses Pembelajaran Matematika. Jurnal Formatif 2 (3). ISSN. 2088-351X. Hal: 248-262.

Wati dan Rahman, Arifin., Meningkatkan Kemampuan Berfikir Kreatif Siswa dengan Model Pembelajaran Berbasis Masalah dalam Mata Pelajaran Kewarganegaraan dikelas VII-a SMP Negeri 2 Lamongan. Artikel Penelitian. Hal: 257-271. 